\title{
Building healthy eating habits in childhood: a study of the attitudes, knowledge and dietary habits of schoolchildren in Malaysia
}

\author{
Kazi Enamul Hoque ${ }^{\text {Corresp., }}{ }^{1}$ ， Megat Ahmad Kamaluddin ${ }^{1}$ ， Ahmad Zabidi Abdul Razak ${ }^{1}$, Afiq Athari Abdul Wahid \\ ${ }^{1}$ Education, Universiti Malaya, Kuala Lumpur, Kuala Lumpur, Malaysia \\ Corresponding Author: Kazi Enamul Hoque \\ Email address: tffr2011@yahoo.com
}

Background: Overweight and obesity have increased rapidly in incidence to become a global issue today. Overweight and obesity problems are significantly linked to unhealthy dietary patterns, physical inactivity and misperception of body image. This study aimed to determine whether Malaysian children build healthy eating habits from childhood.

Methods: A survey on eating habits was conducted among primary school students in standard four to standard six in the state of Selangor, Malaysia. The findings of the study were reported in the form of descriptive statistics involving frequencies and percentages. Data from 400 respondents were analyzed.

Results: Our findings showed that the students understood the definition of healthy food and the types of food that are considered healthy. Although the students knew that food such as deep-fried drumsticks and hamburgers contain a high amount of saturated fat and cholesterol, these foods were still consumed by the students. There was also a high consumption of foods that are fried and contain sugar, salt and saturated fat. In choosing the foods that they eat, two major factors contributed to the students' decisions: cleanliness (65.8\%) and the preference of their parents (12.3\%).

Discussion: Our findings indicate that by implementing the Integrated School Health Program (ISHP) properly, students' eating habits can be improved by creating a school with a healthy environment. 
Building Healthy Eating Habits in Childhood: A Study of The Attitudes, Knowledge and Dietary Habits of Schoolchildren in Malaysia

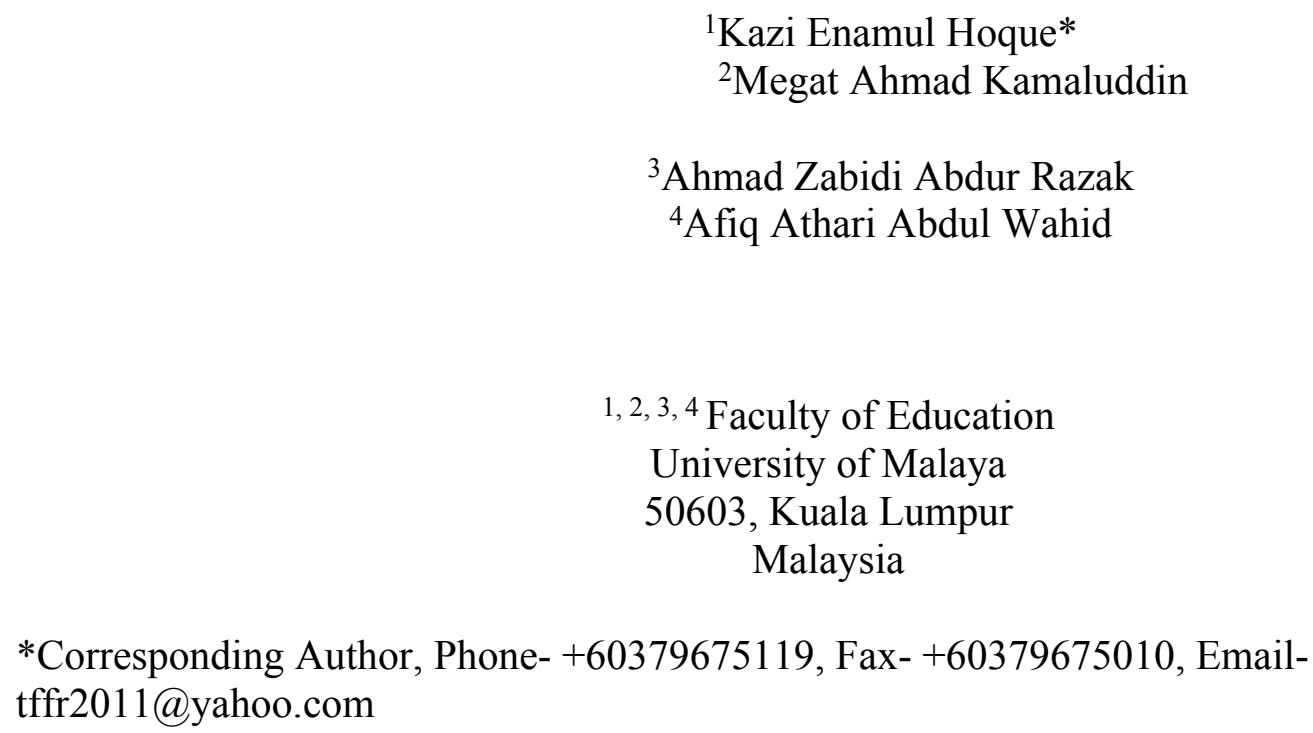

Results: Our findings showed that the students understood the definition of healthy food and the types of food that are considered healthy. Although the students knew that food such as deepfried drumsticks and hamburgers contain a high amount of saturated fat and cholesterol, these foods were still consumed by the students. There was also a high consumption of foods that are fried and contain sugar, salt and saturated fat. In choosing the foods that they eat, two major factors contributed to the students' decisions: cleanliness $(65.8 \%)$ and the preference of their parents $(12.3 \%)$.

Discussion: Our findings indicate that by implementing the Integrated School Health Program (ISHP) properly, students' eating habits can be improved by creating a school with a healthy environment. 


\section{Key Words: Healthy eating, eating habits, school children, Malaysia}

1

\section{Introduction}

Obesity has increased rapidly in incidence to become a global issue today (Kesten, Cameron \& Griffiths, 2013; WHO, 2013). With the vast advancements of the modern world, food is developed in ways that are cheap for consumers but cause the food to contain high amounts of saturated fat and cholesterol (Holliday et al., 2014). But not all fats cause obesity as evidences show that substitution of saturated fat with polyunsaturated fat improves cardimetabolic outcomes (Imamura, 2016). Apart from it, obesity is further exacerbated by the changing lifestyles of individuals, including changes in methods of transportation and a lack of exercise due to work constraints. Obesity is also a risk factor for other non-communicable diseases and is becoming an increasing problem in both developing and developed countries (Ellulu, 2014; WHO, 1998). Obesity is evident among both adults and the younger generation. Studies have shown that overweight and obesity problems are significantly linked to unhealthy dietary patterns, physical inactivity and misperceptions of body image (Egner,Oza-Frank \&, Cunningham, 2014; Sandercock,Voss \& Dye, 2010; Khor et al., 2009; Nagel et al., 2009). Furthermore, according to a study conducted by the Universiti Kebangsaan Malaysia (UKM), the percentage of obese children among primary school students in Malaysia has increased from $9.7 \%$ in 2001 to $13.7 \%$ in 2007 (Norimah A. Karim, 2014). The increase of $4 \%$ within 6 years is an alarming number, and according to Birch (1999), the students involved will have the tendency to continue their food attitudes and eating habits throughout adulthood. Thus, it is important for schools to implement measures aimed at inculcating healthy eating habits as early as the primary school level to develop an ongoing healthy lifestyle. Additionally, the development of a healthy lifestyle is important because a healthy body enhances academic performance (Brown et al., 2007; Egner, Oza-Frank \& Cunningham 2014; Giovannini, Agostoni, \& Shamir, 2010; Pearson, Biddle \& Gorely, 2009). Moreover, schools are uniquely positioned to shape children's eating habits (Gourdet et al., 2014).Thus, the possibility of correcting eating habits is possible through changing the eating habit from low-nutrient, high energy diet to nutritious food and food with sufficient energy. This can be done through education and creating awareness campaign. With this purpose, the Malaysian School Health Program began in 1967 with the main objective of developing students who are productive and healthy. In 2011, Healthy Environment Cabinet Committee (JKPHS) Series No. 1 chaired by the Deputy Prime Minister of Malaysia, Tan Sri Dato' Haji Muhiyiddin bin Haji Mohd Yassin, has decided on strengthening healthy school environments through the implementation of efforts towards a healthy diet and avoid availability of food and unhealthy drinks, in line with the implementation of Program Bersepadu Sekolah Sihat (PBSS) or the Integrated School Health Programme (ISHP) (Ahmad Husairi Khairuddin, 2014). In cooperation with the Ministry of Education and the Ministry of Health, the School Health Program was given the new name of the Program Bersepadu Sekolah Sihat (PBSS), or the Integrated School Health Program (ISHP). The purpose of the program was to synchronize all school activities that are related to health. Some activities that were introduced included the Rancangan Makanan Tambahan (RMT), or the Supplementary Food Program (SFP), which helps provide an adequate nutritional intake for students to ensure a well-balanced diet, and the Program Susu Sekolah (PSS), or the School Milk Program (SMP), which provides fresh milk for students to consume calcium. Other facilities, such as specific rooms for dental care and sick 
bays, were equipped in schools to aid in achieving the objectives of the ISHP. But it is not sure whether students are aware of ISHP objectives. Therefore, a study is necessary to explore students' awareness and the performance of the ISHP programs implemented by the schools.

\section{Materials and Methods}

This was a survey conducted to understand the eating habits of primary school students from standard 4 to 6 within the age range of 10 to 12. Data collection from a large number of students was necessary to generalize the results. There were about 554, 994 primary school students (Standard 1- Standard 6) in Selangor District (Department of Statistics, 2015). The number of students will be fewer (not more than 350,000) from Standard 4 to 6. In accordance with Gay, if the population is 50,000 , a sample size of $1 \%$ would be more than adequate (Gay, 1996). Krejcie \& Morgan (1970) also determined a sample size of 381 for a population of 50,000, 382 for a population of 75,000 and 384 for a population of 100,000. They also suggested a sample size of $1 \%$ is adequate if the population is more than 100,000 . Thus, the sample size (400 students) for this study is more than adequate to truly represent the total population as total students from Standard 4-6 will not be more than 350,000 in Selangor District of Malaysia.

\section{Participants}

There are two types of public schools at the primary level, i.e., the National Schools and the National Type Schools. In the National Schools, the medium of instruction is the Malay language, which is the national language. The medium of instruction in the National Type Schools is either the Chinese language or the Tamil language. In both types of schools, the Malay language is a compulsory subject. English is compulsory and is taught as a second language in all schools. Chinese, Tamil and indigenous languages are also offered as subjects in the National Schools. All three types of public schools are included in this study; these comprise Sekolah Kebangsaan (National Schools), Sekolah Kebangsaan Jenis Tamil (National Type Schools) and Sekolah Kebangsaan Jenis Cina (National Type Schools). Invitations were sent to the respective schools until the number of schools required was achieved. In response to the invitations, the principals were given the responsibility to address the matter with the teachers and students involved in the study. After seeking agreement from the school to participate in the study, a number of teachers involved in the subject of Pendidikan Jasmani dan Kesihatan (PJK), or Physical and Health Education, were asked to choose a class taught from either standard 4, 5 or 6 in order to obtain answers to the questionnaire. 
120

121

122

123

124

125

126

127

128

129

130

131

132

133

134

135

136

137

138

139

140

141

142

143

144

145

146

147

148

149

150

151

152

153

154

155

A structured bilingual version of the questionnaire, comprising Malay and English, was used for the study. A student questionnaire was constructed for the purpose of assessing students in standards 4, 5 and 6 on the current knowledge, attitudes and practices about healthy eating.

The questionnaire was adapted from the Hong Kong Department of Health (Department of Health, 2009), and a pilot study was conducted to either modify or omit questions to suit the context of Malaysian schools. A pilot study was conducted in February 2015 to assess the content validity and comprehensibility of the measurement tools and to test the logistics of the study. Apart from that, before piloting, experts' opinions have been taken and the questionnaire was corrected based on their suggestions to improve the validity. A total of 45 students from three primary schools participated in the pilot study. Fifteen students were invited from each school with the selection of five students from each Grade. These three schools were excluded from the final study. The final questionnaire was revised based on the feedback from the pilot study. The Cronbach's Alpha of the instrument was in between $0.60-0.90$. This pilot study shows that majority of the questions are valid and produce reliable results for analysis thus, no change is needed for the actual survey.

\section{Procedure}

As the primary school children are involved, permission has been taken from University of Malaya Ethics Committee. Between April 15, 2015 and April 19, 2015, 16 participating schools were identified, and the questionnaires were distributed to the students. The representatives involved in this study distributed the questionnaire to all the classes of standards 4,5 and 6 that were chosen. All the students involved were asked to complete the questionnaire during a classroom session. The schools were given 4 weeks to conduct the questionnaires. The completed questionnaires were collected by the teachers. A representative performing the study collected all the questionnaires from all the schools involved. The completed questionnaires were collected from the schools between May 6, 2015 and June 8, 2015.

\section{Data Analysis}

Descriptive statistics is used for all data representation of all survey questions. Generally, descriptive statistics is the easiest form of summarizing data in a presentable format. This simple statistics is performed in Statistical Package for Social Science version 20.0. Some of the most common function used for this survey is frequency, percentage, standard deviation and mean.

\section{Results}

Rate of responses

A total of 600 questionnaires were distributed by the teachers to the students in standards 4,5 and 6 at the 16 participating schools. A total number of 420 answered questionnaires were 
156 returned, resulting in a 70\% response rate. Twenty of these questionnaires were unanswered, and 157 the remaining 400 were used in the analysis. Respondents' demographics

158 Table 1. Characteristics of 400 children aged 10-12 years in standard 4-6 in the state of 159 Selangor, Malaysia

\begin{tabular}{|c|c|c|}
\hline Variables & No. of students & Percentage \\
\hline Grade $(\mathrm{n}=400)$ & 143 & $35.8 \%$ \\
\hline Standard 4 & 97 & $24.3 \%$ \\
\hline Standard 5 & 160 & $40.0 \%$ \\
\hline Standard 6 & & \\
\hline & & $53.5 \%$ \\
\hline Gender $(\mathrm{n}=400)$ & 214 & $46.5 \%$ \\
\hline Male & 186 & \\
\hline Female & & $65.8 \%$ \\
\hline Race $(\mathrm{n}=400)$ & 263 & $11.0 \%$ \\
\hline Malay & 44 & $23.3 \%$ \\
\hline Chinese & 93 & \\
\hline Indian & & \\
\hline School district $(\mathrm{n}=400)$ & 400 & $100 \%$ \\
\hline Selangor & & \\
\hline
\end{tabular}

160

161 Table 1 shows that the majority of respondents (40\%) were students in standard 6 . The 162 respondents also included more male students (53.5\%) and more students belonging to the Malay 163 race $(65.8 \%)$.

164 Students' knowledge of healthier food and their preferences

165 In identifying knowledge about healthy food, six pairs of food were given in the questionnaire. 166 The students were asked to choose the healthiest food among the six pairs. Table 2 indicates that 167 the majority of students understood what healthy foods were based on the correct choices made.

168 In identifying the students' food preferences, the same six pairs of food and drink as the 169 knowledge questions were provided. Table 2 also shows that there was a difference in the 170 answers between the students' preferences and their perceived opinions on what healthy foods 171 are. The percentages of students' food preferences were generally lower. For example, although 172 many students perceived that deep fried drumsticks, hamburgers and fries and fried noodles and 173 chicken are unhealthy foods, more than half of the respondents still preferred eating those foods 174 despite the fact that they are unhealthy choices. 
176 Table 2. Knowledge of healthier food and their preferences of 400 children aged 10-12

177 years in standard 4-6 in the state of Selangor, Malaysia

\begin{tabular}{|c|c|c|c|c|c|c|c|}
\hline \multicolumn{4}{|c|}{$\begin{array}{c}\text { Students' knowledge of healthier food } \\
\text { choices }\end{array}$} & \multicolumn{4}{|c|}{ Students' food preferences } \\
\hline $\begin{array}{l}\text { Healthier } \\
\text { Choice }\end{array}$ & $\%$ & $\begin{array}{l}\text { Unhealthier } \\
\text { Choice }\end{array}$ & $\%$ & $\begin{array}{l}\text { Healthier } \\
\text { Choice }\end{array}$ & $\%$ & $\begin{array}{c}\text { Unhealthier } \\
\text { Choice }\end{array}$ & $\%$ \\
\hline $\begin{array}{l}\text { Soya sauce } \\
\text { drumsticks }\end{array}$ & 55.0 & $\begin{array}{l}\text { Deep fried } \\
\text { drumsticks }\end{array}$ & 45.0 & $\begin{array}{l}\text { Soya } \\
\text { sauce }\end{array}$ & 48.7 & $\begin{array}{l}\text { Deep fried } \\
\text { drumsticks }\end{array}$ & 51.3 \\
\hline $\begin{array}{l}\text { Pure orange } \\
\text { juice }\end{array}$ & 86.3 & $\begin{array}{l}\text { Carbonated } \\
\text { drinks }\end{array}$ & 13.7 & $\begin{array}{c}\text { Pure } \\
\text { orange } \\
\text { juice }\end{array}$ & 79.3 & $\begin{array}{l}\text { Carbonated } \\
\text { drinks }\end{array}$ & 20.7 \\
\hline $\begin{array}{l}\text { Raisin whole- } \\
\text { meal }\end{array}$ & 82.0 & Hot dog & 18.0 & $\begin{array}{c}\text { Raisin } \\
\text { whole- } \\
\text { meal }\end{array}$ & 52.3 & Hot dog & 47.7 \\
\hline Yogurt & 80.0 & Ice cream & 20.0 & Yogurt & 51.5 & Ice cream & 48.5 \\
\hline $\begin{array}{l}\text { Spaghetti with } \\
\text { fresh tomato } \\
\text { sauce }\end{array}$ & 77.3 & $\begin{array}{c}\text { Hamburger } \\
\text { and fries }\end{array}$ & 22.7 & $\begin{array}{l}\text { Spaghetti } \\
\text { with fresh } \\
\text { tomato } \\
\text { sauce }\end{array}$ & 39.8 & $\begin{array}{c}\text { Hamburger } \\
\text { and fries }\end{array}$ & 60.2 \\
\hline $\begin{array}{l}\text { Fried noodles } \\
\text { with vegetables }\end{array}$ & 79.0 & $\begin{array}{c}\text { Fried } \\
\text { noodles } \\
\text { with } \\
\text { chicken }\end{array}$ & 21.0 & $\begin{array}{c}\text { Fried } \\
\text { noodles } \\
\text { with } \\
\text { vegetables }\end{array}$ & 43.8 & $\begin{array}{c}\text { Fried } \\
\text { noodles } \\
\text { with } \\
\text { chicken }\end{array}$ & 56.2 \\
\hline
\end{tabular}

Reasons for not consuming breakfast

A total of $67 \%$, or 268 students, had consumed breakfast on the day of the survey. The students who did not consume breakfast showed different reasons. Table 3 shows that an alarming figure of $56.8 \%$ of the students did not have breakfast because they did not have enough time, and $22.7 \%$ were not in the habit of having breakfast. Another concerning reason was that nobody had prepared breakfast for $7.6 \%$ of them

Table 3. Reasons for not having breakfast of 400 children aged 10-12 years in standard 4-6 in the state of Selangor, Malaysia

\begin{tabular}{|l|c|c|}
\hline \multicolumn{1}{|c|}{ Reason } & No. of students & Percentage \\
\hline I do not have time & 75 & $56.8 \%$ \\
\hline I am on a diet & 2 & $1.5 \%$ \\
\hline I want to save money & 0 & $0.0 \%$ \\
\hline
\end{tabular}




\begin{tabular}{|l|c|c|}
\hline I am not used to having breakfast & 30 & $22.7 \%$ \\
\hline I do not have the appetite to eat in the morning & 15 & $11.4 \%$ \\
\hline No one has prepared breakfast for me in the morning & 10 & $7.6 \%$ \\
\hline Other reasons & 0 & $0.0 \%$ \\
\hline
\end{tabular}

Students' daily dietary habits

191

The students were required to evaluate their daily dietary habits during the week prior to answering the questionnaire. According to Table 4, the percentage of students consuming fruits and vegetables more than twice was, on average, between $44.5 \%$ and $47.0 \%$. However, there was a high occurrence of unhealthy eating habits, such as having deep-fried food and consuming foods high in sugar, salt and saturated fat. Between $60 \%$ and $92.7 \%$ of the students did not reach the recommended frequencies, as shown in Table 5.

Table 4. Eating habits of various food categories on average every day of $\mathbf{4 0 0}$ children aged 10-12 years in standard 4-6 in the state of Selangor, Malaysia

\begin{tabular}{|l|c|c|c|c|c|c|}
\hline \multirow{2}{*}{ Eating Frequency } & \multicolumn{7}{c|}{ Percentage of students } \\
\cline { 2 - 6 } Food Category & $\begin{array}{c}\text { No. of } \\
\text { students }\end{array}$ & $\begin{array}{c}\text { More } \\
\text { than } \\
\text { twice }\end{array}$ & Twice & Once & Never & $\begin{array}{c}\text { Do not } \\
\text { know }\end{array}$ \\
\hline Fruits & 400 & 47.0 & 18.8 & 26.0 & 5.8 & 2.4 \\
\hline Vegetables & 400 & 44.5 & 24.0 & 21.0 & 6.8 & 3.7 \\
\hline Dairy products & 400 & 30.3 & 18.5 & 31.8 & 14.8 & 4.6 \\
\hline Meat, chicken, fish & 400 & 58.5 & 21.5 & 14.5 & 3.0 & 2.5 \\
\hline Grains & 400 & 63.8 & 17.3 & 11.3 & 3.5 & 4.1 \\
\hline Fried and deep-fried food & 400 & 37.0 & 23.8 & 28.8 & 7.3 & 3.1 \\
\hline Drinks with added sugar & 400 & 15.3 & 20.3 & 40.0 & 20.5 & 3.9 \\
\hline Food high in sugar & 400 & 20.2 & 16.2 & 40.1 & 16.0 & 7.5 \\
\hline Food high in salt & 400 & 12.0 & 11.0 & 30.5 & 40.0 & 6.5 \\
\hline Food high in fat & 400 & 24.5 & 17.5 & 39.8 & 11.8 & 6.4 \\
\hline
\end{tabular}

Table 5. Percentage who reached the corresponding recommended frequency of 400 children aged 10-12 years in standard 4-6 in the state of Selangor, Malaysia

\begin{tabular}{|l|c|c|c|}
\hline & & \multicolumn{2}{|c|}{$\begin{array}{c}\text { No. of students/percentage of } \\
\text { students }\end{array}$} \\
\cline { 3 - 4 } $\begin{array}{l}\text { Recommended eating frequency of various } \\
\text { food categories }\end{array}$ & $\begin{array}{c}\text { No. of } \\
\text { students }\end{array}$ & $\begin{array}{c}\text { Reached } \\
\text { recommended } \\
\text { frequency }\end{array}$ & $\begin{array}{c}\text { Not reached } \\
\text { recommended } \\
\text { frequency }\end{array}$ \\
\hline
\end{tabular}




\begin{tabular}{|l|c|c|c|}
\hline Fruit $\geq 2$ times & 400 & $263(65.8 \%)$ & $137(34.2 \%)$ \\
\hline Vegetables $\geq 2$ times & 400 & $274(68.5 \%)$ & $126(31.5 \%)$ \\
\hline Dairy products $\geq 1$ time & 400 & $322(80.5 \%)$ & $78(19.5 \%)$ \\
\hline Meat, chicken, fish $\geq 1$ time & 400 & $320(80.0 \%)$ & $80(20.0 \%)$ \\
\hline Grains $\geq 2$ times & 400 & $255(63.8 \%)$ & $145(36.2 \%)$ \\
\hline Not having fried and deep-fried food & 400 & $29(7.3 \%)$ & $371(92.7 \%)$ \\
\hline Not having drinks with added sugar & 400 & $82(20.5 \%)$ & $318(79.5 \%)$ \\
\hline Not having food high in sugar & 400 & $63(15.8 \%)$ & $337(84.2 \%)$ \\
\hline Not having food high in salt & 400 & $160(40.0 \%)$ & $240(60.0 \%)$ \\
\hline Not having food high in fat & 400 & $47(11.8 \%)$ & $353(88.2 \%)$ \\
\hline
\end{tabular}

Students' knowledge of general healthy eating

206

207

208

209

Based on the two questions asked, there was a lack of healthy eating knowledge by the students because only $27.5 \%$ correctly chose grains as the type of food that should be provided most often in a healthy lunchbox and only $35.8 \%$ knew the correct recommended servings of fruits and vegetables (Table 6).

Table 6. Percentage of students correctly answering the general healthy eating messages

\begin{tabular}{|l|c|c|}
\hline \multicolumn{1}{|c|}{ Healthy eating messages } & $\begin{array}{c}\text { No. of } \\
\text { students }\end{array}$ & Percentage \\
\hline A healthy lunchbox should have more grains & 110 & $27.5 \%$ \\
\hline $\begin{array}{l}\text { A person must consume two servings of fruits and three servings } \\
\text { of vegetables daily }\end{array}$ & 143 & $35.8 \%$ \\
\hline
\end{tabular}

\section{Students' snack eating habits and sources}

Students were shown pictures of snacks before answering whether they had the habit of eating them. The majority of students $(73.3 \%)$ had the habit of snacking; they mostly had homemade snacks $(86.5 \%)$, while $2.3 \%$ bought snacks from the school co-operative shop. Others sources of snacks included outside shops and supermarkets (11.2\%).

Matters for the students' consideration in selecting their food

In the event of choosing food, students were particular regarding the cleanliness of the food: $65.8 \%$ responded to cleanliness as a high priority, followed by $12.3 \%$ responding that the preference of parents determined food choice, as shown in Table 7.

\section{Table 7. Consideration for choosing food of 400 children aged 10-12 years in standard 4-6} in the state of Selangor, Malaysia 
225

\begin{tabular}{|l|c|c|}
\hline \multicolumn{1}{|c|}{ Matters for consideration } & No. of students & Percentage \\
\hline Cleanliness & 263 & $65.8 \%$ \\
\hline Taste & 23 & $5.7 \%$ \\
\hline Good for health & 17 & $4.2 \%$ \\
\hline Freshness & 43 & $10.7 \%$ \\
\hline Price & 4 & $1.0 \%$ \\
\hline Easy to get & 1 & $0.3 \%$ \\
\hline Preference of parents & 49 & $12.3 \%$ \\
\hline Choice of other schoolmates & 0 & $0.0 \%$ \\
\hline
\end{tabular}

226

227 Students' perceived eating habits

228

229

230

231

232

233

234

235

236

237 Support in promoting healthy eating at schools

Figure 1 shows that a total of $45.5 \%$ of students viewed themselves as having very healthy eating habits, and only $1 \%$ considered their eating habits to be very unhealthy

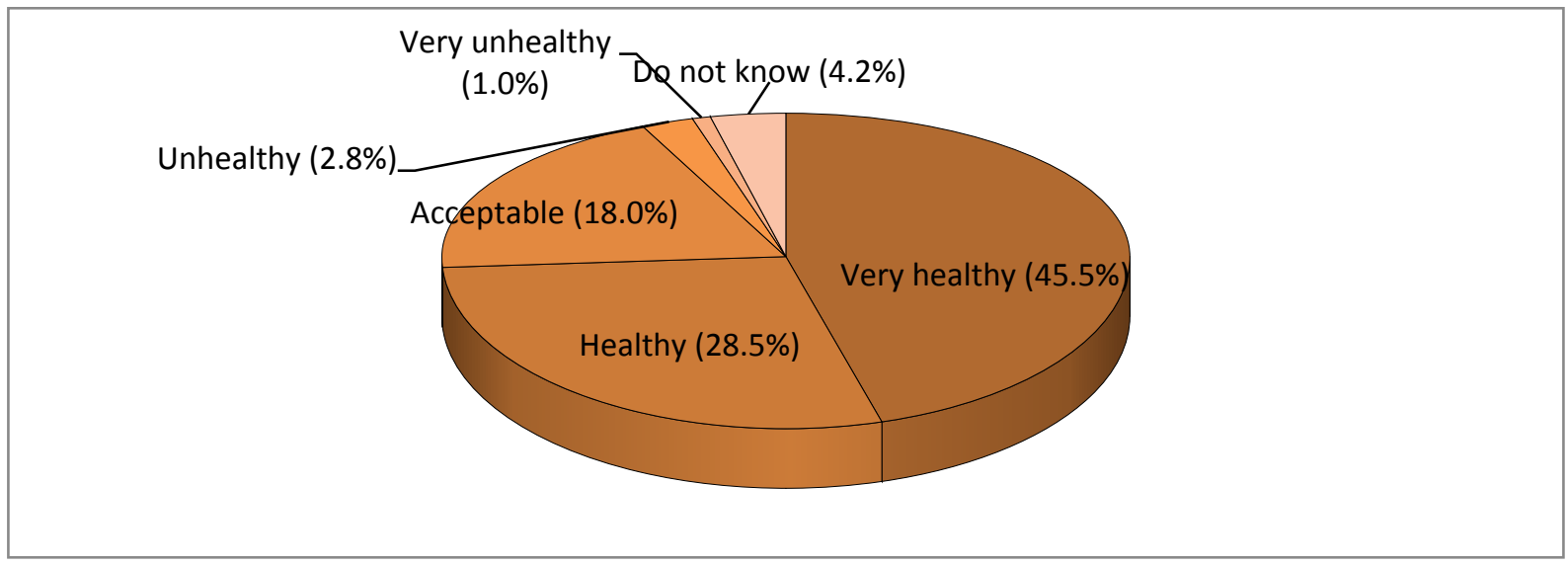

Figure 1. Students' perception of their eating habits: data of 400 children aged 10-12 years in standard 4-6 in the state of Selangor, Malaysia.

Students' awareness of the Integrated School Health Program (ISHP)

More than $45 \%$ of the students had heard of the Integrated School Health Program (ISHP), whereas 55\% did not know about the program. 
238 A total of $77.8 \%$ of the students stated that they supported healthy eating at school, whereas only $2398.8 \%$ of the students were unsupportive of healthy eating. Another $13.4 \%$ did not know whether there was any program of promoting healthy eating at schools.

241

242

243

244

245

246

247

248

249

250

251

252

253

254

255

256

257

258

259

260

261

262

263

264

265

266

267

268

269

270

271

272

273

Participation in school activities promoting healthy eating

Based on the students' responses regarding their participation in school activities that promoted healthy eating in the past year, only $13 \%$ of the students claimed to have been involved. Nearly half of the students $(44.8 \%)$ claimed they were not sure of their participation in these types of activities, and $29.3 \%$ of the students reported that no such activities were ever organized in their schools.

\section{Discussion}

Thus, the ISHP is a program that is still considered important in promoting a healthy eating environment. It is of utmost importance for students to learn healthy eating habits at an early age, thus defining the purpose of implementing the program at the primary level (Gourdet et al., 2014). This survey provides an opportunity to identify the dietary patterns of students and the elements that affect their eating habits. Findings show that the students understand the definition of healthy food but still $50 \%$ of the students consume deep-fried drumsticks and hamburgers containing a high amount of saturated fat and cholesterol. About $60 \%$ of the students have the knowledge of the correct intake of foods such as vegetables, fruits, meats and grains. At the same time, a high percentage of students consume foods that are fried and containing sugar, salt and fat. Parents play an important role in determining the types of snacks as $86.5 \%$ of students responded that the snacks they consumed were taken from their homes. Another finding of not having breakfast (67\%) may cause serious health concern in later life.

Students' perceptions towards eating frequencies in various food categories

In terms of the students' practice in eating healthy foods, there was a high correct response rate regarding the recommendations of the eating frequency in the various food categories. The students responded well in terms of the correct intake of foods such as vegetables, fruits, meats and grains, with an average correct response rate of more than $60 \%$. However, there was a high percentage of students who consumed foods that are fried and contain sugar, salt and saturated fat. This finding is in line with the high percentage of students preferring fried drumsticks in the question regarding the pairs of food. Based on these results, culture is an aspect that can be examined in terms of the types of food consumed. Malaysia is a country that has infused its food based on the different racial backgrounds. Most of the food that can be found and bought in Malaysia is prepared in ways that can be seen as unhealthy. This finding is supported by Ali and Abdullah ( 2012), who stated that current Malaysian foods are sweet, oily and fatty, which has quality in taste but does not consider the aspect of health. Furthermore, with parents spending 
274

275

276

277

278

279

280

281

282

283

284

285

286

287

288

289

290

291

292

293

294

295

296

297

298

299

300

301

302

303

304

305

306

307

308

309

more time at work, students are exposed to foods that are prepared quickly, such as microwaved food in boxes and eating at fast food restaurants, where food can easily be ordered and sent directly to homes. As a result of these factors, the types of food consumed contain ingredients that are high in sugar, salt and fat, leading to unhealthy eating behaviors.

Problems students face in consuming breakfast

Breakfast is considered the most important meal of the day because it helps an individual to work and think during the early part of the day (Pandey et al., 2013). Without breakfast, students may not have the energy to think and perform tasks in class. According to the survey, only $67 \%$ of students had breakfast on the day of the survey. For those who did not have breakfast, 56.8\% responded that not having enough time was their reason for missing breakfast. As such, Singleton \& Rhoads (1982) also identified a lack of time (43\%) as the main factor for not having breakfast. This effect may be due to the problem of time management. In most school systems, school sessions begin as early as 7:30 in the morning, thus requiring students to be in school before 7:30. Students must wake up early and prepare themselves for school. Students using transportation, such as school buses, must prepare themselves even earlier because the buses run early in the morning to pick up all the students in different areas to bring to school. As a result, some students have no time for breakfast and may wait until the morning recess to eat.

\section{Students' perceptions and action towards healthy food}

According to the survey, the majority of students were able to correctly identify the six pairs of food with each pair having a minimum of 55\% correct answers. This finding indicates that the students understood the definition of healthy food and the types of foods that are considered healthy. However, in a question involving those same food pairs and the students' choice of food, there was a difference in the percentage of correct choices. Although the students knew that foods such as deep-fried drumsticks and hamburgers contain a high amount of saturated fat and cholesterol, these food are still consumed by the students, with more than $50 \%$ of the survey population reporting consumption of these foods. Only having knowledge about healthy eating habits is not sufficient; the practical aspect should also be emphasized to students, because there is no purpose of learning without implementing what has been taught (Woodruff \& Hanning, 2009).

\section{Students' habit of snacking}

Snacks can be classified as foods that are eaten between meals or consumed as light meals and can be either healthy or unhealthy. Healthy snacks, such as fruits, vegetables and plain water, contribute to healthy eating and contain no saturated fat or artificial flavors. However, snacks such as chips and sweets contain an excess of ingredients, such as salt and sugar, that can lead to obesity. Moreover, several studies have indicated that the consumption of unhealthy snacks is 
310

311

312

313

314

315

316

317

318

319

320

321

322

323

324

325

326

327

328

329

330

331

332

333

334

335

336

337

338

339

340

341

342

343

344

345

346

347

one of the main contributors to being overweight (De Graaf, 2006). It was found that $73.3 \%$ of students have the habit of snacking, and $86.5 \%$ of students responded that the snacks they consumed were taken from their homes. This finding means that parents play an important role in determining the types of snacks that their children are eating. Parents should set an example for their children and differentiate between healthy and unhealthy food. This conclusion is further supported by Norazia and Mohd Azlan (2012) who stated that families who are poor role models influence the perception of the types of food that their children eat.

Students' factors in choosing food

In choosing the food that they eat, two major factors contributed to the students' decision: cleanliness $(65.8 \%)$ and the preference of their parents $(12.3 \%)$. Cleanliness not only refers to the food but also to the way the food was prepared and the cleanliness of the premises where the food was bought. This finding shows that students are aware of the importance of cleanliness because contaminated food may cause food poisoning, cases of which have been reported in schools. As stated earlier, parents play an important role in determining the types of food their children eat. The results show that parents are aware of their children's eating habits and have influence on the types of food that their children eat. With the influence of parents, children have better guidance in the foods that they consume, which may prevent the consumption of unhealthy foods (Cheng et al., 2008).

Students' perceptions of the ISHP and the implementation of health programs

According to the survey, only $45 \%$ of the students had heard of the ISHP that was implemented by the Ministry of Education. Furthermore, $28.2 \%$ of students had never heard of the program. This result was considered alarming because $40 \%$ of the respondents were in standard 6 and will soon graduate from primary school. Most of the students have been in primary school for 5 or 6 years but had never heard of the program, which may be due to a failure of the school administrators to clarify this program to the students. It is important that the students are always briefed and reminded to help them understand the importance of health and to incorporate awareness into the students' learning process. Failing to implement the program in schools deprives students of knowledge related to health issues. As such, Basch (2010) and Egner et al. (2014) stated that in accordance to scientific reviews, schools that conduct health programs can create positive effects on students' educational outcomes and health outcomes. However, 77.8\% of the students supported their school in events promoting healthy eating, which meant that the students had a positive attitude towards healthy eating events and showed an interest in participating in those activities. Nevertheless, due to a lack of clarity, $44.8 \%$ of the students were uncertain if they had joined the program in the previous year, and $29.2 \%$ stated that their schools had failed to conduct these programs. According to the results, it is important to show that instructions regarding any type of activities are very important. As the target students are in primary school, school administrators and teachers must play their roles in giving specific explanations and specific instructions in order for the students to clearly understand the purpose 
of conducting the programs. School administrators must also take the initiative of implementing more programs related to health. These programs should not be seen as a burden because active involvement from students will benefit them for years to come and will help the students in their future development. As the results show that students are supportive, school administrators should see this as a positive sign to help the students.

\section{Limitations}

Certain limitations were found in this study. This study was limited to upper primary school students of standards 4, 5 and 6 and could be seen as not representing the whole population of primary school students. Furthermore, only 400 participants were chosen, and this study focused only on the state of Selangor. Moreover, the questionnaires were conducted in class under the supervision of teachers and not the representatives of the study. There is a possibility that the students provided answers that did not reflect their actual eating habits.

This study was only limited to student responses, but having responses from parents and the school administration would be more beneficial. With the additional responses of those two elements, the study could correlate the answers of the students, parents and administrators with respect to healthy eating. The data analysis was also limited to only frequencies and percentages.

Another major limitation is that all respondents may not have the similar ability to correctly recall their eating habits or some may over report their status. In questionnaire, the inclusion of grains (rice and noodles) in lunch box has been denoted as healthy. The term 'whole grains' would be more appropriate for further study as highly refined grains have similar effect as added sugars.Nonetheless, the study has provided important information on students' knowledge, attitudes and practices towards healthy eating and the influence of school programs in promoting healthy eating. The results will benefit future programs in helping students at the primary school level.

\section{Conclusions}

The purpose of this study was to assess the knowledge, attitudes and practices of primary school students in healthy eating behaviors. It is concern that students have knowledge of the correct intake of foods but they still consume fried foods containing a high amount of saturated fat, cholesterol, sugar and salt. Most of the students are not having breakfast regularly that may cause serious health problem. Teachers and parents might give more attention to build up a habit of 'breakfast in time' among students. It was evident that school systems are lacking with regard to full implementation of their health programs. The Integrated School Health Program (ISHP) was seen as a key element in inculcating a culture of health-conscious students. As students spend 
410

411

412

413

414

415

416

417

418

419

420

421

most of their time in school, fully utilizing the program is important to help students building healthy eating habit. Furthermore, students will be more committed with the help of teachers and friends. Students can also learn how to turn knowledge and theories into practice. In the students' responses regarding their own eating habits, the majority of students (74\%) considered themselves healthy. By implementing health programs properly, all of the students' eating habits can be improved, thus creating a school with a healthy environment. The results of this study can be utilized by the Ministry of Education to look into improving the Integrated School Health Program (ISHP) for the betterment of students learning a healthy lifestyle. The findings show that implementing more programs at the primary level to promote healthy eating can engage students in learning and practicing these healthy behaviors. Availability of healthier foods such as fruits, vegetables and whole grains in school campus can keep away students of changing the habits of having sugary drinks and fried foods. The school's cooperation with parents in discussing healthy snacks and meals for students to eat at school and at home can create a healthy environment at school.

\section{References}

1. Ahmad Husairi Khairuddin (2014) Program Bersepadu Sekolah Sihat. Retrived from https://prezi.com/qvs0ue4jes3y/program-bersepadu-sekolah-sihat-pbss/ on the date of 25/08/2016.

2. Ali, N. \& Abdullah, M. A. (2012) The food consumption and eating behaviour of Malaysian urbanites: Issues and concerns. Malaysia Journal of Society and Space. 8(6) : $157-165$.

3. Basch, C. E. (2010) Healthier Students Are Better Learners: A Missing Link in School Reforms to Close the Achievement Gap. Equity Matters: Research Review, New York: Columbia University.

4. Birch, L. (1999) Development of Food Preferences. Annual Reviews of Nutrition, 19 (1): $41-62$.

5. Brown, J.E., Isaacs, J., Wooldridge, N., Krinke, B. and Murtaugh, M. (2007) Child and preadolescent nutrition, Nutrition Through the Life Cycle, 3rd ed., Belmone: Thompson Wadsworth; 307-336.

6. Cheng, T.S.Y., Tse, L.A.H., Tak-Sun, Y. and Griffiths, S. (2008) Children's perceptions of parental attitude affecting breakfast skipping in primary sixth-grade students, J Sch Health. 78 (5): 203-208.

7. De Graaf, C. (2006) Effects of snacks on energy intake: An evolutionary perspective. Appetite. 47: 18-23. 
422

423

424

425

426

427

428

429

430

431

432

433

434

435

436

437

438

439

440

441

442

443

444

445

446

447

448

449

450

451

452

453

454

455

456

457

458

459

460

461

462

463

464
8. Department of Health (2009) Assessment of Dietary Pattern in Primary Schools 2008. Hong Kong: Central Health Education Unit.

9. Department of Statistics (2015) Pusat Pentadbiran Kerajaan Persekutuan. Putra Jaya: Malaysia.

10. Egner R, Oza-Frank R, Cunningham SA.(2014) The School Breakfast Program: a view of the present and preparing for the future. J Sch Health. 84: 417-420.

11. Ellulu,M., Abed, Y., Rahmat, A., Ranneh, Y., \& Ali., F. (2014) Epidemiology of obesity in developing countries: Challenges and prevention. Global Epidemic Obesity. 2(2), 1-6.

12. Gay, L.R. (1996) Educational Research: Competencies for Analysis and Application, Florida International University: Prentice Hall.

13. Giovannini, M., Agostoni, C. \& Shamir, R. (2010) "Symposium overview: do we all eat breakfast and is it important?" Critical Reviews in Food Science and Nutrition. 50 (2): 97-99.

14. Gourdet CK, Chriqui JF, Piekarz E, Dang Q, Chaloupka FJ.(2014) Carrots and sticks: compliance provisions in state competitive food laws - examples for state and local implementation of the updated USDA standards. J Sch Health. 84: 466-471.

15. Holliday, A., Batey, C., Eves, FF., and Blannin, A.K.(2014) A novel tool to predict food intake: The Visual Meal Creator. Appetite: 79: 68-75.

16. Imamura, F., Micha, R., Wu, Jayson H.Y., de Oliveira Otto, M.C., Otite, F.O, Abioye, A.I. \& Mozaffarian, D. (2016) Effects of Saturated Fat, Polyunsaturated Fat, Monounsaturated Fat, and Carbohydrate on Glucose-Insulin Homeostasis: A Systematic Review and Meta-analysis of Randomised Controlled Feeding Trials. PLOS Mdicine, http://dx.doi.org/10.1371/journal.pmed.1002087

17. Kesten, J.M., Cameron, N. and Griffiths P. L.(2013) Assessing community readiness for overweight and obesity prevention in pre-adolescent girls: a case study. BMC Public Health: 13: 1205

18. Khor, G.L., Zalilah, M.S., Phan, Y.Y., Ang, M., Maznah. B., \& Norimah, A. K. (2009) Perceptions of body image amongMalaysian male and female adolescents. Singapore Med J. , 50(3): 303.

19. Krejcie, R.V. \& Morgan,D.W.(1970) Determining sample size for Research Activities. Educational and Psychological Measurement, 30: 608.

20. Nagel, G., Wabitsch, M., Galm, C., Berg, S., Brandstetter, S., Fritz, M., Klenk, J., Peter, R., Prokopchuk, D., Steiner, R., Stroth, S., Wartha, O., Weiland, S.K. and Steinacker, J. (2009) Determinants of obesity in the Ulm research on metabolism, exercise and lifestyle in children (URMEL-ICE). European Journal of Pediatrics. 168(10) : 1259-1267. 
465

466

467

468

469

470

471

472

473

474

475

476

477

478

479

480

481

482

483

484

485

486

487

488

489

490

491

492

493

494

495

496

497
21. Norimah A. Karim (2014) Growing big and Round. Positive Parenting- Retrived from http://mypositiveparenting.org/2014/02/05/growing-big-and-round/ on the date of February 10, 2014.

22. Pandey, D., Buzgeia, M.H., Suneetha, E., Ahmed, H., Al Gani, Honida A. E. R., Al Kadam, H.A.E.R. \& Elariby, N.J (2013) Breakfast skipping pattern among Benghazi primary school children. British Food Journal, 115 (6): 837-849.

23. Pearson, N., Biddle, S.J.H. \& Gorely, T. (2009) Family correlates of breakfast consumption among children and adolescents: A systematic review, Appetite. 52(1): 1-7.

24. Sandercock, G.R., Voss, C. and Dye, L. (2010) Associations between habitual school-day breakfast consumption, body mass index, physical activity and cardiorespiratory fitness in English schoolchildren, European Journal of Clinical Nutrition, 64(10) : 1086-1092.

25. Singleton, N., \& Rhoads, D. S. (1982) Meal and snack patterns of students. J Sch Health, 52: $529-534$.

26. World Health Organization (2013) Factsheets. Geneva: WHO media centre.

27. World Health Organization(1998) Information Series on School Health: Healthy Nutrition: An Essential Element of a Health-Promoting School. Geneva.

28. Woodruff, S.J. and Hanning, R.M.(2009) Effect of meal environment on diet quality rating, Canadian Journal of Dietetic Practice and Research. 70(3): 118-124. 